\title{
Cantar i contar la història en el barroc
}

\author{
Albert Rossich \\ Universitat de Girona. Institut de Llengua i Cultura Catalanes ${ }^{1}$ \\ https://orcid.org/0000-0002-7463-866X
}

\section{Resum}

Aquest article resumeix els continguts principals dels treballs aplegats en aquest dossier monogràfic, que es dedica a l'estudi de diversos relats de memòria pública i privada del barroc. Justifica l'oportunitat i rellevància d'aquest dossier, n'introdueix els objectius i ofereix un resum de cada article.

Paraules clau: barroc; literatura; Catalunya; València; edat moderna

Resumen. Cantar y contar la historia en el Barroco

Este artículo resume los principales contenidos de los trabajos reunidos en este dosier monográfico, consagrado al estudio de diversos relatos de memoria pública y privada del barroco. Justifica la oportunidad y relevancia de este dosier, expone sus objetivos y ofrece un resumen de cada artículo.

Palabras clave: barroco; literatura; Cataluña; Valencia; Edad Moderna

\section{Abstract. To sing and to tell the history during the Baroque}

This article summarizes the main contents of the works in this monographic dossier. It argues for the timeliness and relevance of this dossier, presents its aims and provides a summary of each article.

Keywords: Baroque; literature; Catalonia; Valencia; Early Modern Age

1. Aquest dossier s'inscriu en la línia de recerca del projecte FFI2015-70095-P. Alguns dels treballs aquí recollits van ser presentats per primera vegada al col-loqui Les confluències artístiques de la literatura barroca, celebrat a la Facultat de Lletres de la Universitat de Girona els dies 1-3 de març de 2017, i s'han reelaborat per adequar-se a les necessitats d'aquest aplec; d'altres, en canvi, s'han encarregat per a l'ocasió. 
Abans de la «invenció», al segle XVIII, del concepte de literatura de creació, el mot literatura era sinònim de cultura escrita. Els tractats mèdics o jurídics, la historiografia, la pedagogia, la dietarística, les relacions de successos, els memorials... tot això era considerat literatura. El dossier «Cantar i contar la història en el barroc» busca aproximar-se, des de diverses disciplines i defugint els gèneres tradicionalment considerats com a «història», a la narració del relat dels esdeveniments coetanis d'aquest període. Ho fa a partir de casos concrets, des del bandolerisme fins a les festes (de Santa Eulàlia, o de les exèquies del bisbe Dimas Lloris), passant per la relació del setge de Girona de 1653 o la construcció autobiogràfica de la valenciana Rosa de Santo Domingo, i des de l'àmbit públic, a partir de les relacions impreses, o des de la memòria privada, continguda generalment en còdexs manuscrits. Però si hi ha un fil conductor que lliga tots aquests estudis, a part de la literaturització de la història, és la propaganda. La literatura, des d'antic i fins als nostres dies, ha servit per legitimar (o deslegitimar) el poder, per cantar i per contar: per cantar-ne les gestes o les derrotes; per contar la història des d'un determinat punt de vista.

En primer lloc, l'estudi de Cristina Fontcuberta ens aproxima a les festes de Santa Eulàlia amb motiu de l'extensió universal del res de la patrona de la ciutat de Barcelona. Per mitjà dels Festivos y magestuosos cultos - la relació de festes que es va publicar el 1686 per commemorar l'efemèride- i d'altres escrits coetanis que les descriuen —els dietaris institucionals-, Fontcuberta s'ocupa d'analitzar un espectacle total en què conflueixen diverses arts i sentits: la vista, l'oïda i l'olfacte, i ho fa resseguint la descripció de l'art produït per a l'ocasió: piràmides, escultures, pintures, gravats, etc. Les unes conservades, efímeres les altres, tot plegat respon a un programa de propaganda ben orquestrat per la ciutat, el relleu de la qual apareix sovint darrere de les imatges de la santa, i que podia ser observat per tots els seus habitants, que participaven activament en les celebracions.

Les relacions de successos, en prosa i en vers, són d'una gran importància per entendre la generalització del discurs propagandístic en el Sis-cents. Aquests textos, sovint de caràcter polític, es difonen per mitjà de la protopremsa, que es consolida a tot Europa al llarg de la primera meitat del segle XVII. Es tracta d'impresos de baix cost, dels quals es distribuïen un nombre elevat de còpies, que són especialment importants per diverses raons: era la literatura de consum general, que es podia llegir en privat o en veu alta, en l'espai reclòs d'una casa o a les places i carrers, i, a més, generava uns ingressos substancials als impressors, fet que n'incentivava la producció. Les contribucions d'Alejandro Llinares i Sergio Moreno hi fan referència a partir de dos episodis històrics concrets, com hem avançat: el bandolerisme i el setge de Girona de 1653. La darrera, a més, analitza el transvasament que es produeix entre gèneres literaris, en aquest cas, de la relació de successos al teatre.

Així, Llinares estudia la propaganda que va generar el bandolerisme en forma de plecs solts al llarg del Sis-cents i al Principat. L'estudi amplia la nòmina coneguda de literatura de cordill, popular o popularista, referida al fenomen i es fixa especialment en dos episodis, que es corresponen amb els dos anys de més pro- 
ducció de tota la centúria: per una banda, el 1606, coincidint amb les cobles que s'escriuen per promoure la signatura de les unions i agermanaments de les vegueries contra els bandolers, i, per una altra, el 1616, quan Albuquerque té la necessitat de justificar les mesures repressives contra els bandolers. Tot plegat li permet analitzar diversos aspectes polítics i socials que s'hi reflecteixen, com ara les parcialitats, els (habituals) conflictes entre virrei i institucions del Principat, la prostitució o la visió dels catalans des de Castella, entre d'altres.

Per la seva banda, Moreno parteix de les relacions del setge de Girona per explicar com Moreto les aprofita per a la seva peça dramàtica De fuera vendrá (1654), que és, a la vegada, una reescriptura de ¿De cuándo acá nos vino? de Lope de Vega (1615). La poca distància temporal entre el fet històric, l'aparició de les relacions de successos que el narraven i la factura de l'obra de teatre, ens fa veure, d'entrada, com era d'habitual la reutilització de materials en la construcció de la literatura de l'època. El cas de Moreto no és una excepció entre els autors del seu temps. A partir de la comparativa de l'obra del dramaturg amb les sis relacions en castellà sobre el setge de Girona que coneixem, publicades en diverses ciutats hispàniques (Madrid, Girona, Barcelona, Saragossa, Granada, Sevilla), s'identifica la relació (o relacions) que l'autor castellà degué tenir entre les mans i s'analitza com es construeix el discurs de la comèdia: es trien els passatges més substancials, que es poden fins i tot copiar literalment, i es manté l'ordre del discurs de la relació que es pren com a font (que no sempre és el cronològic). Aquestes relacions funcionen, doncs, com un hipotext de l'obra literària. La permeabilitat de les manifestacions literàries, la seva confluència, queden ben patents en aquesta anàlisi que ens ofereix Moreno del De fuera vendrá de Moreto.

Atenent a la seva difusió, la literatura memorialística se situa en un terreny ben diferent del que és la literatura de plec solt o les relacions de festes. S'adreça a un públic més reduït, més específic. Tot i això, aquesta literatura privada o semiprivada és també testimoni d'uns fets presents i respon a la ideologia dels seus autors (que, si no busquen atènyer un públic ampli, no tenen la necessitat de censurar-se) o dels seus promotors (que busquen consolidar el seu àmbit d'influència o controlar les manifestacions escrites que hi fan referència).

Arantxa Llàcer, a «Festa pública i memorialística a la Barcelona barroca», s'ocupa de la festa barroca a la ciutat comtal a través de la memòria pública, és a dir, la de les institucions, i també de la privada. Partint de la base que la necessitat de «fer memòria» és connatural als homes, sigui en la forma que sigui (dietaris, memòries, noticiaris, llibres de comptes, etc.), l'estudiosa valenciana analitza un cas concret, la relació de les exèquies del bisbe de Barcelona Joan Dimas Lloris a finals del segle XVI, que permet extrapolar de manera general com es narra en primera persona un esdeveniment festiu. Tot plegat li permet concloure que la memòria pública i la privada no han de ser compartiments estancs, sinó que el relat històric es pot construir, des d'avui, a partir d'un puzzle de memòries que ens forneixen un relat complementari d'un mateix esdeveniment.

En un àmbit privat, el de l'escriptura autobiogràfica d'una religiosa, però ja a finals del barroc i amb el canvi de paradigma que propugna l'il.luminisme emergent, se situa l'estudi de Verònica Zaragoza sobre la valenciana Maria Antònia 
Ortolà, coneguda amb el nom de Rosa de Santo Domingo. La vida espiritual d'aquesta dona, els processos inquisitorials en què s'havia inculpat ella mateixa (per heretgia i per haver mantingut relacions sexuals amb el dimoni) o els papers que se li han atribuït, redactats majoritàriament amb la voluntat de contribuir a un procés que en certifiqués la fama de santedat, permeten a Zaragoza traçar-ne una biografia en què es discerneix entre autorepresentació - real i imaginada alhora-, per una banda, i representació pública, per una altra, en la mesura que els seus actes són descrits i avaluats per individus aliens a la protagonista. L'examen i la condemna de les seves vivències se'ns presenten com una mostra de l'interès de l'Església per enaltir i dignificar la vida conventual femenina.

Els cinc estudis d'aquest recull conformen un mosaic prou ampli de la voluntat d'explicar la història i de difondre ideologia des de la literatura. Es tracta d'una panoràmica feta a partir d'episodis concrets i que es podria ampliar amb molts altres fets, però que ens permet fer-nos una idea de com es construeix el discurs històric més enllà de la història. 